\title{
Final report of IGCP Project 410 (1997-2002) - The Great Ordovician Biodiversification Event
}

\author{
1. Department of Earth and Planetary Sciences, Macquarie University, North Ryde, NSW 2109, Australia. \\ E-mail: bwebby@laurel.ocs.mq.edu.au \\ 2. Department of Earth Sciences, University of California, Riverside, CA 92521, U.S.A. \\ 3. UPR du CNRS Géosciences, Université de Rennes I, 35042 Rennes-cedex, France.
}

In 1997, IGCP Project No. 410 was established to appraise known records of Ordovician biotas, in order to evaluate one of the greatest-ever diversifications of life on Earth, between 489 and 443 million years ago. Data collection and analysis of biodiversity were coordinated through seven regional teams, and a global "clade" team. A web-based relational database was employed for input of results. Some 200 workers from 38 countries participated, resulting in approximately 1,000 publications. Global and/or regional diversity trends were determined for most fossil groups down to species level, and many other relevant aspects such as bioevents, biofacies, impacts of changing geographic and environmental regimes, and ocean and climatic states were studied. A new, highly resolved, well-calibrated, and wholly integrated Ordovician timescale was established to allow precise local- to global-scale correlations of biodiversity data, and a standardized set of diversity measures developed to provide a consistent basis for communicating biodiversity results. The global Ordovician Radiation exhibited more-or-less uninterrupted biodiversity increase from the beginning of Ordovician time, but was punctuated by dramatic, more intensive, step-wise pulses of diversification through the Mid to Late Ordovician, prior to the glacially induced End Ordovician mass extinction. The events included a bewildering array of adaptive radiations of Cambrian-, Palaeozoic- and Modern-type evolutionary biotas in marine habitats, the first animals (arthropods) to walk on land, and the first plants (non-vascular bryophytelike forms, based on cryptospore records) to colonize damp sites on land-all of these pivotal in shaping future evolutionary pathways.

\section{Introduction}

IGCP 410_-"The Great Ordovician Biodiversification Event"- was voted as one of the most successful projects in the 30-year history of the joint UNESCO-IUGS research programme by the IGCP Scientific Board. The primary goal of the project was to thoroughly appraise the records of preserved biotas in Ordovician rocks world- wide, as a basis for comprehensively evaluating how this greatest, most rapidly sustained (46-million-year-long) interval of diversification of marine life took place on earth, from 489 to 443 million years ago. This event represents the second great Paleozoic evolutionary radiation in the history of life after the Cambrian explosion of skeletonized animals 540 m.y. ago.

The ambitious task required major efforts to develop a more highly refined and well-calibrated Ordovician timescale so that the rates of diversity change across various fossil groups could be calculated and compared much more precisely than previously. The timescale is now presented in our recently published book documenting the "The Great Ordovician Biodiversification Event" (Webby et al., 2004; see Figure. 1). The second important prerequisite of this biodiversity study was to have the fossil data collected with minimal sampling biases, and compiled using a uniform set of diversity measures that could be applied consistently across all fossil groups, allowing more meaningful comparisons of patterns of diversity change to be made.

Other aspects of the work involved identifying the significant Ordovician global (and regional) bioevents, and analyzing the onshore-offshore biofacies profiles across latitudinal belts. An overview of the significant physical and chemical features of the Ordovician world was also considered an essential background part of the project. Plate tectonic movements, changing climate, fluctuations in sea level, and pulses of volcanic activity were topics, for example, thought likely to have been influential in shaping the great diversification of life. Many of these issues are covered in the wealth of IGCP 410 publications (some 1,000 contributions listed on our website; see http://www.es.mq.edu.au/mucep/igcp410/), and some are summarized in six chapters (Part II-Conspectus of the Ordovician World) of our Ordovician biodiversity book (Webby et al., 2004).

IGCP 410 was established initially with a well-planned, dual, regional and clade team, management structure to coordinate the collection and analysis of biodiversity data on a regional basis, and to assess independently the biodiversity patterns of main taxonomic groups through time and space in a complementary, globally based,



Figure 1 Illustration of the cover of the landmark volume of IGCP 410: Webby, B.D., Paris, F., Droser, M.L., and Percival, I.G., eds., 2004. "The Great Ordovician Biodiversification Event". Columbia University Press, New York, $x+484 \mathrm{pp}$. Note that the use of a modern nautiloid on the cover (chosen by the publisher) was more allegorical than factual. 
work. A web-based relational database was employed to input relevant biotal and other data, and the new Ordovician timescale developed using a wholly integrated stratigraphic framework and key zonal indices tied to a 19 time-slice subdivision and radiometric dates (Table 1). This finely divided time scale formed the basis for global, regional and local correlations, and also for assessing the patterns of diversity change and rates of turnover in the Ordovician biotas down to species level.

From the beginning, we sought a global focus enlisting the support of Ordovician workers from as many countries as possible, especially from developing countries. Running this IGCP project was a complex and, at times, logistically difficult task for the leaders but we still managed to maintain close contact with members in various ways, through an IGCP 410 Circular providing updates of news at irregular intervals (about 20 were distributed by electronic mail), that included such details as forthcoming meetings and work plans; and an IGCP 410 website (see address details above), was maintained by Peter Cockle, Webmaster at the Macquarie University Centre for Ecostratigraphy and Palaeobiology. We also circulated a first issue of the IGCP 410 Newsletter by surface mail in June 1998 (Webby 1998b), but was the last because of the high postal costs and slowness of mail distribution worldwide. Networking continued using e-mailed circulars, the dedicated website, and from 1999, regular publication of our annual reports in Ordovician News, this latter through the courtesy of Guillermo Albanesi (editor of the Ordovician Subcommission's Newsletter). The IGCP 410 website continues to be maintained and includes details of the project, reports of activities through 2000 to 2002 and a comprehensive bibliography of relevant work published from 1997 to 2004, most of which remain available for downloading in pdf format.

During the six years, 1997-2002, IGCP 410 held, or actively participated in, 16 international and regional meetings (11 being globally most significant), with ten accompanied by major field excursions of relevance (see list below). The IGCP Scientific Board rated the project highly - from "Excellent" to "Excellent (Plus)" in its final year.

The project was the first to highlight exclusively Ordovician rocks and fossils. IGCP 410 also collaborated with other relevant IGCP projects and other major international programmes. It formed an enduring linkage with IGCP 421 ("North Gondwanan
Mid-Palaeozoic Biodynamics Bioevent/Biogeography Patterns in Relation to Crustal Dynamics"), the two projects being associated in Australia (1997, 2000, 2002), and in the joint field meetings to SW Siberia and Mongolia in 2001 (see below). It shared interests with IGCP 406 ("Circum-Arctic Palaeozoic Vertebrates") in studies of Arctic Canadian, Russian and Baltic Ordovician microvertebrates (and associated biotas). Also cordial and cooperative relationships existed with Subcommission on Ordovician Stratigraphy (ISOS) of the IUGS (International Union of Geological Sciences) most notably establishing the more refined time scale. We also supported the concept of GOES (Global Ordovician Earth Systems), proposed by S.C Finney and W.B.N. Berry (USA) in 1996, which aimed to stimulate integrated multidisciplinary research on global Earth Systems problems in the Ordovician.

\section{IGCP 410 meetings}

1997-At the Working Group on Ordovician Geology of Baltoscandia (WOGOGOB), St Petersburg, Russia (49 scientists from 15 countries attended) [Koren', T.N., ed., 1997; Popov, L.E., ed., 1997], work plans for the regional teams developed. Also, at the Geological Society of America annual meeting, Salt Lake City, Utah; the French Palaeontological Association/Geological Society of France meeting, Lyon; and the Association of Australasian Palaeontologists' conference, Wollongong [Wright, A.J., ed., 1997] - the latter two with IGCP 421.

1998 - International Symposium "Paleodiversifications: Land and Sea Compared", Université Claude Bernard, Lyon, (23 Ordovician scientists from 9 countries) [Gayet, M., and Otero, O., eds., 1998]-included IGCP 410-acknowledged global palaeo-diversity presentations. Meeting in South Korea (7-12 September), at Seoul National University with 22 scientists from 7 countries [Choi, D.K., ed., 1998], followed by a field trip to Taebaegsan area [Choi, D. K., and Lee, D.-J. 1998] to examine Ordovician platform successions that formed as part of an extensive, near-equatorial, North ChinaKorea block. Then activities in China that included: a field trip to the classic Yangtze Gorges area (supported by the Yichang Institute of Geology \& Mineral Resources of the Chinese Ministry of Geology

Table 1. Outline of the Ordovician global stratigraphic framework and the time-slice subdivisions as used in the volume entitled 'The Great Ordovician Biodiversification Event' (modified from Webby, in Webby et al. 2004).

$a-B r i t i s h$ Hirnantian = upper Ashgill interval; $b$-British Llanvirn = middle to upper parts of the Darriwilian Stage; $c-B r i t i s h$ Arenig $=$ interval from upper Lower through lower Middle to lower Darriwilian (inclusive). Formalized global subdivisions are shown in bold; all other subdivisions remain informal. IUGS-ratified global boundary stratotype sections and points (GSSPs) are depicted by thicker dotted lines at bases of Tremadocian Stage, upper Lower interval, Darriwilian Stage, 'Caradoc' interval and overlying Silurian (top of 'Ashgill' interval), respectively. Symbol: N/A = no subdivisions applied.

\begin{tabular}{|c|c|c|c|c|c|}
\hline System/Period & Series/Epoch & Stage/Age & Substage/Subage & Time Slices & $M a$ \\
\hline \multirow{6}{*}{$\begin{array}{l}\mathbf{O} \\
\mathbf{R} \\
\mathbf{D} \\
\mathbf{O} \\
\mathbf{V} \\
\mathbf{I} \\
\mathbf{C} \\
\mathbf{I} \\
\mathbf{A} \\
\mathbf{N}\end{array}$} & \multirow[t]{2}{*}{ Upper/Late } & 'Ashgill' & $\begin{array}{l}\text { upper/latea } \\
\text { middle/mid } \\
\text { lower/early }\end{array}$ & $\begin{array}{l}6 c \\
6 b \\
6 a\end{array}$ & $43-$ \\
\hline & & 'Caradoc' & $\begin{array}{l}\text { upper/late } \\
\text { middle/mid } \\
\text { lower/early }\end{array}$ & $\begin{array}{l}5 d \\
5 b-c \\
5 a\end{array}$ & \\
\hline & \multirow[t]{2}{*}{ Middle/Mid } & Darriwilian $^{b}$ & $\begin{array}{l}\text { upper/late } \\
\text { middle/mid } \\
\text { lower/earlyc }\end{array}$ & $\begin{array}{l}4 \mathrm{c} \\
4 \mathrm{~b} \\
4 \mathrm{a}\end{array}$ & 460- \\
\hline & & lower Middle/early Mid & N/A & $\begin{array}{l}3 \mathrm{~b} \\
3 \mathrm{a}\end{array}$ & \\
\hline & \multirow[t]{2}{*}{ Lower/Early } & upper Lower/late Early ${ }^{\mathrm{c}}$ & N/A & $\begin{array}{l}2 \mathrm{c} \\
2 \mathrm{~b} \\
2 \mathrm{a}\end{array}$ & \\
\hline & & Tremadocian & $\begin{array}{l}\text { upper/late } \\
\text { middle/mid } \\
\text { lower/early }\end{array}$ & $\begin{array}{l}1 d \\
1 b-c \\
1 a\end{array}$ & 489 \\
\hline
\end{tabular}


\& Mineral Resources) [Wang, X.-F., ed., 1998]; meeting at the Nanjing Institute of Geology \& Palaeontology (NIGP) of Academia Sinica, with 35 scientists from 11 countries; and a NIPG-organized field excursion to Jiangshan-Changshan-Yushan area, Zhejiang and Jiangsi provinces [Rong, J.-Y., Zhou, Z.-Y. and Chen, X., 1998]. This excursion included, as part of our interlinked activities with the Ordovician Subcommission (ISOS), a dedication of the graptolite Undulograptus austrodentatus Monument (Figure 2), at the site of the Global Stratotype Section and Point (GSSP) for the base of the global Darriwilian Stage, Huangnitang section, near Changshan (see Mitchell et al. 1997). Barry Webby, IGCP 410 Project Leader and former Chair of ISOS, officiated at the unveiling ceremony. Mu Xinan, Director of NIPG, Zhejiang Provincial and the Changshan County government officials and many other Chinese and foreign scientists, also participated.

1999-Associated with 8th International Symposium on the Ordovician System (ISOS) held at Charles University, Prague, Czech Republic (with 81 scientists from 21 countries). Included a joint CIMP (Commission Internationale de Microflore du Paléozoique)/ IGCP 410 seminar [Kraft, P., and Fatka, O., eds., 1999; Servais, T., and Paris, F. eds., 2001], regional and clade teams, and database workshop discussions with demonstration of website database procedures; pre-symposium field trip to Poland and Germany [Dzik, J., Linnemann, U., and Heuze, T., 1999]; and post-symposium field trips to classic Barrandian area [Kraft, J., Kraft, P., and Fatka, O., eds., 1999] to see good examples of characteristic, cooler, higher palaeolatitude-type Ordovician biotal successions. Symposium of Spanish IGCP 410 working group at Museo Geominero (Madrid) with 15th Annual meeting of the Spanish Palaeontological Association; participants from six countries [Gutiérrez-Marco, J.C. ed., 1999].

2000-Meeting in Orange (New South Wales) at the Australasian Palaeontological Convention (APC-2000), with 45 scientists from 10 countries [Cockle, P., Wilson, G.A., Brock, G.A., Engelbretsen, M.J., Simpson, A., and Winchester-Seeto, T., eds., 2000], and two field trips in central New South Wales [Percival, I.G., Pickett, J.W., Sherwin, L., and Webby, B.D., 2000] to examine shelf- to slope-type successions and biotas of off-Gondwanan, nearequatorial, Ordovician volcanic island-arc sites. At the 31 st International Geological Congress, Rio de Janiero, Brazil, presented session 2-7 ("The Great Ordovician Biodiversification Event: Significance of Biotal Patterns in both Regional and Global Contexts")[GutiérrezMarco J.C., and Albanesi G.L., co-convenors, 2000].

2001- "Clade"-team meeting at University of California, Riverside, with 45 scientists from 13 countries [Holroyd, P.D., ed., 2001; Webby, B.D. Paris, F., and Droser, M.L., 2001a; Webby, B.D., Paris, F., Droser, M.L., and Percival, I.G., eds., 2004; Figure 3]; and see "Clade" team report, below). Combined IGCP410/421 field meeting to examine Ordovician to Early Carboniferous successions of the Gorniy Altai, Salair and Kuznetsk Basin, SW Siberia, and visit geological survey facilities at "Zapsibgeols'emka", Ministry of Natural Resources of Russia, Novokuznetsk, and the Institute of Petroleum Geology, Siberian Branch, Russian Academy, Novosibirsk [useful guidebook, in Yolkin, E., Talent, J.A., and Webby, B.D., eds., 2001]. Joint IGCP410/421 Mongolian field meeting studied Ordovician to Mid Palaeozoic sequences and biotas at Mushgai, Shine Jinst (Gobi Desert), and Bayankhongor (with 37 participants from nine countries); also technical sessions held at Mongolian Technical University in Ulaan Bator [excellent



Figure 2 The Darriwilian GSSP monument at the Huangnitang section, near Changshan, Zhejiang province, SE China.

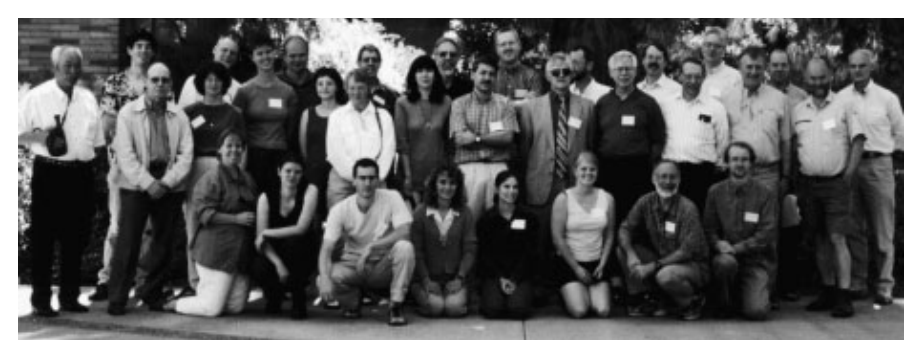

Figure 3 A group photo of the participants who attended the IGCP 410 "clade"-team meeting on the Riverside campus, University of California, USA, in June 2001.

85-page guidebook and Ordovician-Silurian correlation chart of Mongolia in Minjin, Ch., and Tumenbayer, B., organizers/compilers, 2001]. Biogeographically distinctive coral faunas examined at localities in the Gobi Desert, and diverse, well-preserved Ordovician biotas near Bayankhongor, central Mongolia. The WOGOGOB meeting in Copenhagen, Denmark, focussed on the development of the Ordovician biodiversity database in Baltoscandia [Harper, D.A.T., and Stouge, S., eds., 2001]. Meeting on "Early Palaeozoic palaeogeographies and palaeobiogeographies of western Europe and North Africa" in the Université des Sciences et Technologies de Lille, Villeneuve d'Ascq, France, included workshops on Ordovician map reconstructions and related patterns of Ordovician biodiversity change in North Gondwana [Servais, T., Álvaro, J.J., and Blieck, A., eds., 2003].

2002-At First International Palaeontological Congress (IPC), Macquarie University, Sydney, hosted session "The Response of the Marine Biosphere to Major Changes within the Earth System during the Ordovician" (with 40 scientists from 15 countries) [Brock, G.A. and Talent, J.A., eds., 2002]; also a joint IGCP 410/421 field trip to examine Ordovician-Silurian graptolite successions of SE Australia [VandenBerg, A.H.M., Wright, A.J., Percival, I.G., Sherwin, L., and Rickards, R.B., 2002]. The requested one-year extension of the project allowed time to complete the global synthesis of Ordovician biodiversity (Webby et al., 2004; and Figure 1), and opportunity to convene this last meeting of IGCP 410 meeting in conjunction with the IPC.

\section{Scientific achievements}

\section{Regional teams}

Seven regions, Europe/Africa, Baltoscandia, China/Korea, Kazakhstan/Middle Asia/Siberia, North America/South America and Australasia provided an underlying framework. The teams were requested to undertake four main tasks: (i) collection of biotal range data from local sections and areas; (ii) assessment of these data in terms of localized biofacies and biostratigraphy; (iii) the integration of these data with the regional correlation and palaeogeographic frameworks; and (iv) lastly, incorporation of this data in still wider (global) syntheses, as a basis for elucidating overall patterns of biodiversity change, and the factors that might have influenced the change.

Much of the collection and compilation of biodiversity data down to species level, along with the differentiation of biofacies patterns, was carried out within the framework of coordinated work programs of the regional teams. The Europe-Africa group has been, significantly, the most active and productive regional team, thanks to the continued efforts of co-leader and regional team chairperson, Florentin Paris. Important progress has been made also in Baltoscandia, China/Korea, and Australasia. Activities in North America have been less comprehensive, centred mainly in the Great Basin and Appalachians, while in South America progress has been confined to areas in Argentina, notably in the Precordillera and Cordillera Oriental. The results represent mainly local and regional biodiversity work, i.e., activities covered by work programme tasks i-iii (above). The bulk of the published work of IGCP 410, as listed on the web- 
site, falls into the category of regional team activities - innumerable contributions employing the data to establish local and regional biodiversity patterns, and also to evaluate relevant taxonomic, biostratigraphic, palaeoecologic and palaeozoogeographic aspects of that data. The patchy overall progress of regional team programmes, however, makes it impossible yet to attempt wider global syntheses of task iv, as originally envisaged.

\section{Databases}

An essential part of the various work programmes, enthusiastically encouraged because of the dispersed distribution of contributors worldwide, was to have easy access to a large, computerized, relational database with links to a website for direct inputting of fossil occurrence data via the internet. During the initial stages of the project there were two main groups developing excellent relational databases for Ordovician biotal studies. The website developed by Arnold Miller (University of Cincinnati) was adopted for the inputting of IGCP 410 data from 1999. Access to entries in this database should be sought through: http://www.uc.edu/geology/faculty/miller.html

A second, large, relational database was developed for Ordovician biotas of the British Isles by Alan Owen and colleagues at Glasgow University (Scotland).

Other smaller, more specialist, taxonomic databases were developed, especially by workers involved in the global "clade"team work, for their compilations and analyses of global and regional diversity patterns of specific fossil groups (e.g., chitinozoans, graptolites, etc.). These compilations are now incorporated in the book "The Great Ordovician Biodiversification Event" (Webby et al., 2004).

Cooperative efforts are needed from all workers with Ordovician databases to interlink them, so we have a single, easily accessible, reliable, web-based research tool for future Ordovician biodiversity work worldwide.

\section{"Clade" team}

An independent global "clade" team programme was established in 1998 to assess how each taxonomic group evolved through Ordovician time, in diversifications that represent the Ordovician Radiation (alternatively, referred to as the Great Ordovician Biodiversification Event). The collection and analysis of genus- and species-level data was undertaken on a group-by-group basis to establish the temporal and spatial patterns of global (and regional) biodiversity change, and the rates of turnover.

Leading specialists from many parts of the world participated in these surveys, working either as individuals, or in small to large teams, to assemble these compilations for each taxonomic group. This global biotal survey of "clade" group data was the focus of the meeting in 2001 at the University of California, Riverside (Figure 3). The results are now published in the volume entitled "The Great Ordovician Biodiversification Event" (Figure 1). The book includes introductory chapters dealing with the scaling of Ordovician time (divided into 19 time slices; see Table 1), and the favoured measures for depicting diversity change, together with chapters that briefly appraise the Ordovician world-topics such as major terranes, isotopic signatures, oceans and climate, a possible superplume event, end Ordovician glaciation and sea level change. Then follows the comprehensive data analysis and interpretation of biodiversity patterns for most known taxonomic groups, some closing remarks on the Ordovician Radiation, and an expansive bibliography - a total of 35 chapters contributed by 96 authors from 17 different countries. The book highlights the "clade"-team work programme, and gives the first broadly encompassing treatment of one of the greatest diversification events in earth history. Compared with the earlier Cambrian explosion, the Ordovician Radiation was a more sustained diversification, and the communities were more specialized and competitive, with narrower ecological requirements and use of resources.
All three "Great Evolutionary Faunas" (EFs) of Sepkoski (1997)-Cambrian EF, Paleozoic EF, and Modern EF-played a part in the Ordovician Radiation. They are somewhat fuzzy sets of unrelated higher taxa with similar histories of diversification through extended intervals of time. Components of the Cambrian EF (e.g., linguliformean brachiopods, ?Ibex trilobites) were mainly subordinate, except in the Early Ordovician, while members of the Paleozoic EF (e.g., rhynchonelliformean brachiopods, cephalopods, crinoids, graptolites, conodonts, Whiterock trilobites, ostracodes, bryozoans, corals) were dominant, especially in the Mid and Late Ordovician. Elements of the Modern EF were also subordinate except for two mollusc groups (gastropods, bivalves), that continued to radiate through Ordovician time.

Among the larger, predominantly benthic, groups, the trilobites have been separated into discrete family-level clusters-Ibex I \& II and Whiterock faunas - each with markedly different diversification histories. The Ibex I \& ?II faunas seem best referred to Sepkoski's Cambrian EF, and the Whiterock fauna, a component part of the Paleozoic EF. The Ibex faunas radiated predominantly early, during the Early-Mid Ordovician, and did not survive the end Ordovician mass extinction, whereas the Whiterock fauna diversified mainly through the Mid-Late Ordovician, surviving into the Silurian. The brachiopods are divided into different subphyla that have very different diversification histories. Linguliformean brachiopods are components of the Cambrian EF, and exhibited two pulses of diversification in the Early Ordovician, before becoming subordinate members in most environments. The rhynchonelliforms, in contrast, are major elements of the Paleozoic EF: they have an Early Ordovician record of diversification of two higher-level groups (orthidines, pentamerides), then show a dramatic increase in levels of diversification as many more higher-level groups appeared, in a spectacular, exponential, Mid-Late Ordovician rise in diversity, with major, mid Caradoc and early Ashgill peaks.

Other benthic groups also show predominantly Mid-Late Ordovician biodiversity highs. The bryozoans, for example, first appeared in the Early Ordovician (Tremadocian), but did not radiate markedly until the Mid-Late Ordovician when all the main groups except one diversified in an exponential rise. This dramatic increase extended from Darriwilian, to maxima in the mid Caradoc and early Ashgill, and then dramatically declined. The stromatoporoid sponges are another group that exhibits a somewhat similar pattern of diversification with overall diversity increase through the Late Ordovician, then sharp end Ordovician decline. Coral-, and algal- groups (reds, greens and browns) also showed rather similar patterns and timing of diversity change.

Among the pelagic groups, the graptolites, after a slow start at the beginning of the Ordovician, expanded spectacularly in successive diversification pulses, first in the late Early Ordovician (Table 1), then less intensively later, in mid Darriwilian and mid Caradoc events, each apparently corresponding to a global highstand interval. The conodonts are depicted as exhibiting important diversification pulses in the late Tremadocian and early Mid Ordovician, while the chitinozoans, after first appearing early in the Ordovician only started to diversify intensively during the Mid Ordovician-to a maximum in the late Darriwilian followed by a secondary mid Caradoc peak. So, whereas some pelagic elements (graptolites, conodonts) radiated markedly during the Early Ordovician, suggesting decoupling of pelagic and benthic realms, the pelagic chitinozoans radiated predominantly in the Mid-Late Ordovician, in accord with the major benthic diversifications.

Two other features of this biodiversity research may be mentioned. First, that many groups exhibit the high point of their specieslevel diversification during the mid Caradoc (e.g., echinoderms, chitinozoans, bryozoans, hyoliths, vertebrates, tetradiid corals, cyclocrinitid algae), whereas a few others have their species-level diversity high later, during the early-mid Ashgill (e.g. radiolarians, stromatoporoids). These great diversification pulses seem likely to coincide with global sea level highstands. Secondly, although most fossil groups suffered substantial taxonomic losses related to the major regression associated with end Ordovician glaciation and 
mass extinction, a few, small, mainly cosmopolitan groups, such as the radiolarians, scolecodonts (polychaete jaws) and miospores survived unscathed, with their diversity largely intact across the Ordovician-Silurian boundary interval.

\section{The future}

Although the IGCP project has achieved many positive results, much remains to be done to more fully understand the nature and likely causes of the great Ordovician radiation event. There are a host of topics of relevance to Ordovician biodiversity studies that remain poorly understood, such as:

- Plankton ecology and productivity of the Ordovician oceans;

- The overall impact of microbial life in all environmental settings of the Ordovician;

- The reconstruction of trophic webs and assessment of nutrient levels;

- Fully integrated analyses of all the main Ordovician ecosystems, from terrestrial to the open ocean, and across latitudes;

- Fullest possible documentation of biodiversity data in at least two other major continental platform areas with complete and well preserved Ordovician biodiversity records (e.g., Baltoscandia, South China) to rigorously test against the known patterns of onshore-offshore diversity change recognized across the North American platform; and

- Intensive documentation of biotas from the comparatively few well-exposed and well-preserved "windows" of island, islandarc, and oceanic segments.

In addition, there are topics of broader geological significance that have, at least, equally important and relevant implications for the understanding of Ordovician biodiversity change. We still need global syntheses of Ordovician volcanic and orogenic histories, a more fully integrated and rigorously tested global Ordovician sea level curve, and an improved understanding of global continental and oceanic configurations through Ordovician time. The preliminary work on the last two topics (comparisons between the Baltoscandian and North American sea level curves, and on a number of aspects of plate tectonics) by IGCP 410 workers is an excellent start, but the only satisfactory long-term solution will be first to undertake fully comprehensive, well integrated, worldwide analyses of the volcanic, orogenic, sea level and plate tectonic histories, and then to attempt to assess their respective roles in influencing the major Ordovician patterns of diversity change. We still do not know with any certainty what activated the profound levels of marine diversification - the warm greenhouse conditions and the extremely high eustatic sea levels were probably important, but what role did the atmosphere play given that carbon dioxide levels were 14-18 times higher than the present, and oxygen only about 50 percent of presentday levels?

Many of these important issues will be addressed in the new IGCP Project 503: "Ordovician Palaeogeography and Palaeoclimate" (2004-2008), proposed by Thomas Servais, Axel Munnecke, Dave Harper, Jun Li, Alan Owen and Peter Sheehan. They plan to continue the cooperative approach with geologists, geochemists, geophysicists, and scientists actively involved in past climatic and oceanographic modelling work. Such a multidisciplinary program will consider earth-system processes and modelling of past climate and oceanographic change. They need to develop links with the GOES (Global Ordovician Earth Systems) program currently being reactivated by Stan Finney, Chris Barnes and Bill Berry. The interactive roles and responses to changing atmospheric compositions, ocean chemistry and patterns of ocean circulation will have been critically important for the Ordovician biosphere, and therefore vitally important and relevant matters for our future understanding of the Ordovician radiations. Details including the first meeting at the University of Erlangen are available from the following website: http://www.pal.uni-erlangen.de/IGCP503/

\section{References}

Álvaro, J.J., and Servais, T., compilers, 2001, Early Palaeozoic Palaeogeographies and Biogeographies of Western Europe and North Africa. Université des Sciences et Technologies de Lille, Villeneuve d'Ascq, September, 24-26, 2001. Abstracts volume, $72 \mathrm{pp}$.

Brock, G.A. and Talent, J.A., eds., 2002, First International Palaeontological Congress (IPC 2002), Geological Society of Australia, Abstracts no. 68, 297 pp. Sydney, Australia [Abstracts of 40 IGCP 410-related papers].

Choi, D.K., ed., 1998. Abstracts with Program for IGCP Project No. 410 Field Meeting to Korea. Institute of Geological and Environmental Sciences, Seoul National University, Korea, pp.i-ii, 1-38. [Comprises 10 separate contributions]

Choi, D. K., and Lee, D.-J. 1998. Guidebook for IGCP 410 Field Meeting to Korea: Ordovician stratigraphy and paleontology of the Taebaegsan region, Korea. Institute of Geological and Environmental Sciences, Seoul National University, Korea, pp. i, 1-63. [Plus two unpublished Field Guide Supplements I \& II for sections at Gumunso and Yondang]

Cockle, P., Wilson, G.A., Brock, G.A., Engelbretsen, M.J., Simpson, A., and Winchester-Seeto, T., eds., 2000, Palaeontology Down Under 2000, Geological Society of Australia, Abstracts no. 61, 183 pp. [Includes 40 papers relevant to IGCP 410].

Crame, J.A., and Owen, A.W., eds., 2002, Palaeobiogeography and Biodiversity Change: the Ordovician and Mesozoic-Cenozoic Radiations. Geological Society London, Special Publication 194, 206 pp. [Five papers acknowledge IGCP 410].

Dzik, J., Linnemann, U., and Heuze, T., 1999, Excursion guide: Poland and Germany. 8th International Symposium on the Ordovician System, Prague 1999, Pre-Conference Field trip, 69 pp.

Gayet, M., and Otero, O., eds., 1998, Paléodiversifications: terres et mer comparées - résumes, Symposium International. Abstracts volume, 77 pp., Lyon, France. [Contains 13 IGCP 410-related abstracts].

Gutiérrez-Marco, J.C. ed., 1999, Contribuciones paleontológicas al Proyecto 410 del Programa Internacional de Correlación Geológica (IUGSUNESCO). Acta Geological Hispanica v. 34, pt.1, 101 pp. [Includes a preface and two research papers on IGCP-410 themes].

Gutiérrez-Marco J.C., and Albanesi G.L., co-convenors, 2000, The Great Ordovician Biodiversification Event: Significance of Biotal Patterns in both Regional and Global Contexts. Abstracts of IGCP 410 Session 2.7, in CD-ROM of the 31st International Geological Congress, Rio de Janiero, Brazil. [14 IGCP 410-related abstracts].

Harper, D.A.T., and Stouge, S., eds., 2001, Abstracts, Working Group on the Ordovician Geology of Baltoscandia (WOGOGOB - 2001), 47 pp. [Includes 16 IGCP 410-related abstracts].

Holroyd, P.D., ed., 2001. IGCP 410: The Great Ordovician Biodiversification Event - Abstracts. PaleoBios, v. 21, no. 2, 2nd Supplement, 14 pp. [Contains 28 IGCP 410 abstracts].

Koren', T.N., ed., 1997, Meeting of Working Group on Ordovician Geology of Baltoscandia (WOGOGOB-97). A.P. Karpinksii All-Russian Geological Research Institute (VNIGRI), Ministry of Natural Resources and Russian Academy of Sciences, Programme and Abstracts, 63 pp. St Petersburg, Russia. [Includes 12 IGCP-410-related abstracts].

Kraft, P., and Fatka, O., eds., 1999, Quo vadis Ordovician?. Short papers of the 8th International Symposium on the Ordovician System (Prague, June, 20-25, 1999). Acta Universitatis Carolinae, Geologica, v. 43, pts.1/2, 534 pp. [Contained 72 short papers on IGCP 410-related themes].

Kraft, J., Kraft, P., and Fatka, O., eds., 1999, Excursion guide: Barrandian. 8th International Symposium on the Ordovician System, Prague 1999, Post-Conference Field Trip, 60 pp.

Minjin, Ch., and Tumenbayer, B., compilers, 2001, The Guide Book, Abstracts \& Ordovician-Silurian Correlation Chart for the Joint Field Meeting of IGCP 410 and IGCP 421 in Mongolia. Parts I-IV, 127 pp. Mongolian Technical University, Ulaanbaatar, Mongolia. [An updated version volume also exists; it has the same date but may be identified by the "ISBN 99929" printed on its front cover, a different pagination (131 pp.), and re-numbered figures].

Mitchell, C.E., Chen Xu, Bergström, S.M., Zhang Yuan-dong, Wang Zhihao, Webby B.D. and Finney S.C., 1997. Definition of a global boundary stratotype for the Darriwilian Stage of the Ordovician System. Episodes v. 20 (3), pp.158-166.

Percival, I.G., Pickett, J.W., Sherwin, L., and Webby, B.D., 2000, Biostratigraphy and biodiversity of Ordovician volcanic islands in the Lachlan Orogen, New South Wales. Geological Survey of New South Wales, Palaeontological Report 2000/01 (Geological Survey Report No. GS 2000/410): 47 pp. [An IGCP 410-field trip guidebook]. 
Popov, L.E., ed., 1997, WOGOGOB Excursion Guide, St. Petersburg, Russia. 24 pp., 25 figs. Department of Historical Geology and Palaeontology, Uppsala University, Sweden.

Rábano, I., ed., 1999, Actas XV Jornadas de Paleontologia y Simposios de los proyectos 393, 410 y 421 del PIGG. Simposio Proyecto PIGG 410. Temas Geológico-Mineros ITGE, v. 26, pp. 519-588, Madrid, Spain [Includes 13 IGCP 410-related papers].

Rong, J.-Y., Zhou, Z.-Y. and Chen, X., 1998, Abstracts and Programme: International Symposium on the Great Ordovician Biodiversification Event (IGCP Project No. 410). Laboratory of Palaeobiology and Stratigraphy, Nanjing Institute of Geology and Palaeontology, Academia Sinica, Special Issue, Palaeoworld, v.10, 47 pp. [Comprises 23 contributions].

Sepkoski, J.J., Jr. 1997. Biodiversity: Past, present, and future (Presidential Address). Journal of Paleontology v. 71, pp.533-539.

Servais, T., 1998, An annotated bibliographical review of Ordovician acritarchs. Annales de la Société Géologique de Belgique v. 120, pp.47-79.

Servais, T., Álvaro, J.J., and Blieck, A., eds., 2003, Early Palaeogeographies and palaeo(bio)geographies of western Europe and North Africa. Palaeogeography, Palaeoclimatology, Palaeoecology v. 195, 228 pp. [Five IGCP-acknowledged papers]

Servais, T., and Paris, F. eds., 2001, Ordovician palynology and palaeobotany. Review of Palaeobotany \& Palynology v. 113, nos. 1-3, 212 pp. [Special Issue, dated December 2000 with 13 contributions; based on IGCP410/CIMP Prague seminar].

VandenBerg, A.H.M., Wright, A.J., Percival, I.G., Sherwin, L., and Rickards, R.B., 2002, Ordovician-Silurian graptolite succession of southeastern Australia. First International Palaeontological Congress (IPC 2002), Post-2 Field Excursion Guidebook; 66 pp. [IGCP 410/421 postcongress field trip guide].

Wang, X.-F., ed., 1998. Field Trip Guide, IGCP Project No. 410: The Ordovician in the Yangtze Gorges area. Yichang Institute of Geology and Mineral Resources, MGMR, 19 pp.

Webby, B.D., 1998a, Steps toward a global standard for Ordovician stratig raphy. Newsletters in Stratigraphy v. 36, pp.1-33

Webby, B.D., ed., 1998b, IGCP Project No. 410, The Great Ordovician Biodiversification Event, IGCP 410 Newsletter, no. 1, 28 pp

Webby, B.D. Paris, F., and Droser, M.L., 2001a, IGCP Project No. 410 - The First, Globally Collaborative Project to Study the Great Ordovician Biodiversification Event (1997-2001). Poster displayed at the "clade" team meeting, University of California, Riverside, U.S.A. [prepared by Florentin and Olivier Paris].

Webby, B.D., Paris F. \& Droser, M.L., 2001b, IGCP Project No. 410: Five Years of Ordovician Biodiversity Activities Worldwide. Poster displayed by Edward Derbyshire (Chairman, IGCP Board) at the Geological Society of America and Geological Society of London's Joint Global Meeting on Earth Systems Processes, Edinburgh, UK. [prepared by Barry D. Webby].

Webby, B.D., Paris, F., Droser, M.L., and Percival, I.G., eds., 2004. The Great Ordovician Biodiversification Event. Columbia University Press, New York, $\mathrm{x}+484 \mathrm{pp}$

Wright, A.J., ed., 1997, Palaeobiogeography of Australasian Faunas and Floras, University of Wollongong, Geological Society of Australia, Abstracts and Programme no. 18, pp. i-xxi, 1-117, Sydney [Contains 13 IGCP 410-related abstracts]

Yolkin, E., Talent, J.A., and Webby, B.D., eds., 2001. Contributions to Siberian IGCP 410/421 Joint Meeting. Parts I-IV, 110 pp. Institute of Petroleum Geology, Russian Academy of Sciences, Siberian Branch, Russia, and Centre for Ecostratigraphy and Paleobiology, School of Earth Sciences, Macquarie University, 2109, Australia.

\section{Acknowledgments}

We acknowledge particularly UNESCO and the IUGS, and the members of the IGCP Scientific Board who supported IGCP 410 for six years and provided both encouragement and medium/high to high level funding support. They, together with a number of regional organizations, helped us sponsor highly successful meetings in each year of the project to one or more different parts of the world.

The following individuals and their organizations were especially supportive in arranging our globally focused meetings: Tatjana N Koren' (A.P. Karpinsky All-Russian Geological Research Institute - VSEGEI, St Petersburg, Russia), Duck K. Choi (Institute of Geological and Environmental Sciences, Seoul National University, Korea), Rong Jia-yu, Zhou Zhi-yi and Chen Xu (Laboratory of
Palaeobiology and Stratigraphy, Nanjing Institute of Geology and Palaeontology, Academia Sinica, China), Wang Xiao-feng (Yichang Institute of Geology and Mineral Resources, MGMR, China), Mireille Gayet and Olga Otero (Université Claude Bernard, Lyon, France), Petr Kraft and Oldrich Fatka (Institute of Geology - Palaeontology, Charles University, Prague, Czech Republic), John Talent, Ruth Mawson and Glen Brock (Centre for Ecostratigraphy and Palaeobiology, Macquarie University, North Ryde 2109, Australia), Ian Percival (Geological Survey of New South Wales, Lidcombe, Australia), Mary Droser (Department of Earth Sciences, University of California at Riverside, U.S.A.), Evgeny Yolkin (Institute of Petroleum Geology, Russian Academy of Sciences, Novosibirsk, Russia), and Minjin Chuulin (School of Geology, Mongolian Technical University, Ulaanbaatar, Mongolia). At the 31st International Geological Congress in Brazil, both Juan Carlos Gutiérrez Marco (Instituto de Geologia Economica, CSIC-UCM, Madrid, Spain) and Guillermo L. Albanesi (CONICET-Museo de Paleontologia, Universidad Nacional de Córdoba, Argentina) kindly acted as co-convenors of the IGCP 410 session. We also thank Sue Turner (Queensland Museum, Australia) for her helpful comments on earlier drafts of this report, and Peter Cockle (at Macquarie University's Centre for Ecostratigraphy \& Palaeobiology) for maintaining the IGCP 410 website.

Barry D. Webby is a senior palaeontologist at the Centre for Ecostratigraphy and Paleobiology, Macquarie University, Australia. His interests are mainly in fields of Ordovician research, especially in relation to the timescale, global patterns of reef development, and to biodiversity. From 1989 to 1996 he was Chair of the Subcommission on Ordovician Stratigraphy, and is currently coordinating author of the calcified sponge volume of the "Treatise on Invertebrate Paleontology".



Mary L. Droser is a professor in the Department of Earth Sciences, University of California at Riverside, U.S.A. She has major interest in the early evolution of animals and their habitats, and has published widely on aspects of trace fossils, ichnofabrics and patterns of ecologic change in Phanerozoic infaunal communities.

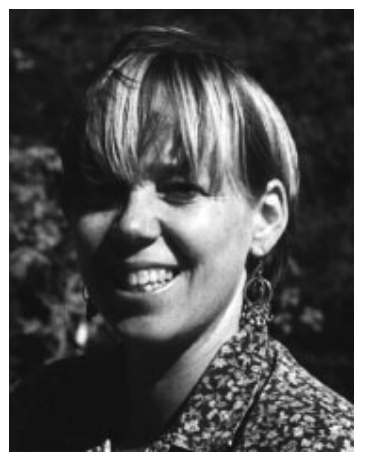

Florentin Paris is a CNRS research director in Geosciences at the University of Rennes, France. He has worked on biostratigraphic, palaeobiogeographic, palaeoenvironmental and biodiversification aspects of the major Ordovician-Devonian, organic-walled microfossil group, the chitinozoans. He is currently President of the Commission International de Microflore du Paléozoique and a member of the IGCP Scientific Board.



